\title{
Autoimmune Disorder, CTCAE
}

National Cancer Institute

\section{Source}

National Cancer Institute. Autoimmune Disorder, CT CAE. NCI Thesaurus. Code C143310.

A disorder characterized by loss of function or tissue destruction of an organ or multiple organs, arising from humoral or cellular immune responses of the individual to his own tissue constituents. 